\title{
Fluoride Adsorption by Pumice from Aqueous Solutions
}

\author{
AMIR HOSSEIN MAHVI ${ }^{1,2,3}$, BEHZAD HEIBATI $^{1 *}$ \\ ALIREZA MESDAGHINIA $^{1}$, AND AHMAD REZA YARI ${ }^{4}$
}

${ }^{1}$ School of Public Health, Tehran University of Medical Sciences, Tehran, Iran

${ }^{2}$ National Institute of Health Research, Tehran University of Medical Sciences, Tehran, Iran

${ }^{3}$ Center for Solid Waste Research, Institute for Environmental Research, Tehran University of Medical Sciences, Tehran, Iran

${ }^{4}$ University of Medical Sciences and Health Services, Qom, Iran

bheibati@gmail.com

Received 6 August 2011; Accepted 4 October 2011

\begin{abstract}
Drinking water provides many vital elements for the human body, but the presence of some dissolved elements more than permissible concentration can endanger human health. Among the dissolved elements in drinking water, fluoride is noticeable, because both the very low or very high concentrations have adverse health impacts such as dental caries. Therefore, fluoride concentration should be kept in acceptable levels. In this study Pumice was used for fluoride removal. It was found that Fluoride sorption kinetic was fitted by pseudo-second-order model. The maximum sorption capacity of Pumice was found to be $13.51 \mathrm{mg} / \mathrm{g}$ at laboratory temperature $\left(24^{\circ} \mathrm{C}\right)$. Maximum sorption study occurred at $\mathrm{pH}=3$. Results of Isotherm showed the fluoride sorption has been well fitted with Freundlich isotherm model. This study has demonstrated that Pumice can be used as effective adsorbents for fluoride removal from aqueous solutions. The adsorbent prepared in this study was cheap and efficient in removal of fluoride than other adsorbents.
\end{abstract}

Keywords: Fluoride removal, Pumice, Adsorption isotherm, Aqua solution.

\section{Introduction}

Water always contains some dissolved material, suspended solids, and dissolved gasses. The presence of some of the dissolved materials are necessary for health, but, presence of them more than the permissible concentrations may lead to health problems. The concern about chemical ingredients in drinking water is different from that of microbial agents, because unlike chemical agents they need more time to show adverse impacts ${ }^{1}$. Similar to some natural elements, fluoride can enter the body by inhalation and ingestion of food and water and influence our health. Nearly $80 \%$ of fluoride entered into the body is excreted mainly via urine. 
But fluoride residue is absorbed into the body tissues ${ }^{2}$. Constant and frequent contact with fluoride results in a condition in the body called enamel Fluorosis. We can see the impact of fluoride in a mild colorization of dental surfaces to sever staining, enamel loss, and pitting. These conditions remain permanent in the body after dentification in childhood from birth till 8 years of age $^{2}$. The prevalence of disease related to fluoride in various parts of the world is different; including reports of $100 \%$ prevalence of fluorosis in Senegal and Tanzania ${ }^{3-4}$ and $67 \%$ prevalence in Larestan Township and Bandare Lengeh in $\operatorname{Iran}^{5}$. On the other hand, studies show that the fluoride concentration in the range of zero to $0.5 \mathrm{mg} / \mathrm{L}$ may cause dental caries ${ }^{6}$. So, the concentration of fluoride in drinking water resembles a two-edged knife. That is both high and low concentration of it are harmful ${ }^{7-8}$. Although, other fluoride sources exist to enter the body, water and water-based beverages have the maximum share of received fluoride by individual $^{9}$. Depending on the age of persons, $57-90 \%$ of total fluoride intake comes from water consumption with $2 \mathrm{mg} / \mathrm{L}$ of concentration, and in the case of $4 \mathrm{mg} / \mathrm{L}$, the share will get $72-94 \%{ }^{10}$. The concentration of fluoride in most of the black tea is very high and can increase the daily intake in human ${ }^{11}$. So, waters with very high concentration of sodium, potassium, chloride, and little calcium, contain very high levels of fluoride as well ${ }^{12}$. On the whole, because more contact time of groundwater with stone bed, the concentration of fluoride in groundwater is more than surface water ${ }^{13}$. Several methods have been applied to remove excessive fluoride from aqueous solution such as adsorption ${ }^{14-15}$, precipitation ${ }^{16}$, ion-exchange ${ }^{17}$, electrodialysis $^{18}$ and reverse osmosis ${ }^{19}$. Among these methods, Adsorption is a common process that has been used extensively, because of its simplicity and the availability of a wide range of adsorbents. Various materials such as activated alumina ${ }^{20}$, activated carbon ${ }^{21}$, fly ash ${ }^{22}$, bone char $^{23}$, Florex ${ }^{24}$, activated bauxite ${ }^{25}$, zeolites ${ }^{26}$ and resin $^{27}$ have been successfully tested for drinking water defluoridation. Pumice is a volcanic rock that is a solidified from of volcanic lava and can be found in many places around the world. Also, in Iran, this rock can abundantly be found in many parts mostly in Azerbaijan. Pumice has high porosity, light weight and normally either floats on water or sinks slowly. It has high levels of silica, about 60-70 percent of weight. Silica with the chemical formula of $\mathrm{SiO}_{2}$ is quartz. The Mohs' Hardness for Pumice is $5-6^{28}$. In this study, the adsorption of fluoride from agues solutions by Pumice has been assessed. The physicochemical and morphological characteristics of Pumice was analyzed by X-ray diffraction (XRD), scanning electron micrographs (SEM) and XRF (X-ray fluorescence).Further, the potential of Pumice was assessed for sorption of fluoride.

\section{Experimental}

All chemicals used in this study were purchased from Merck Co. Pumice was obtained from Azerbaijan, Iran. Fluoride stock solution was prepared by dissolving $\mathrm{NaF}$ in distilled water. Standards and fluoride spiked samples at required concentrations were prepared by appropriate dilution of the stock solution with deionized water. The concentration of fluoride in the solution was determined by UV-Visible spectrophotometer Lambda 25 (PerkinElmer). Fluoride analysis was carried out by following SPADNS method. A known volume of sample was taken in a $25 \mathrm{~mL}$ volumetric flask and addition of $5 \mathrm{~mL}$ of SPADNS reagent to it. The volume was made up to $25 \mathrm{~mL}$ using distilled water and the absorbance was measured at $570 \mathrm{~nm}^{29}$.

\section{Characterization of the Sorbent}

The surface and textural morphology of Pumice was determined by scanning electron micrographs (SEM) using XL30 (Philips), Field emission LaBb scanning electron microscope. The physicochemical characteristics are determined by measuring point of zero charge $\left(\mathrm{pH}_{\mathrm{PZC}}\right)$, by $\mathrm{x}$-ray diffraction $(\mathrm{XRD})$ using a Bruker AXS D8 Advance x-ray diffractometer and by XRF (X-ray fluorescence) analysis. 


\section{Preparation of Pumice}

Pumice used in the study was obtained from Azerbaijan. To enhance the porosity of Pumice and also to remove its impurities, Pumice was pretreated in acid solution $(\mathrm{HCl})$ at $\mathrm{pH}=1$, for $24 \mathrm{~h}$ at room temperature, being rinsed with double DW several times until effluent turbidity reached to lower than $0.1 \mathrm{NTU}$ and then dried at $103{ }^{\circ} \mathrm{C}$ for $36 \mathrm{~h}$. Finally, the raw sample was grounded by a primary crusher (hammer type), and then sieved to particle size fraction of 30 mesh screen.

\section{Fluoride Sorption Studies}

Batch experiment was carried out to measure the adsorption characteristics of fluoride by the Pumice. The Pumice $(0.8 \mathrm{~g})$ was added to $150 \mathrm{~mL}$ of synthetic fluoride solutions of varying concentration (2-10 $\left.\mathrm{mg} \mathrm{L}^{-1}\right)$. After equilibrium, samples were filtered and the filtrate was then analyzed for residual fluoride concentration. Amount of sobbed fluoride $\left(\mathrm{q}_{\mathrm{e}}(\mathrm{mg} / \mathrm{g})\right)$ can be computed by following formula:

$$
q_{e}=\frac{\left(C_{0}-C_{e}\right) V}{M}
$$

where, $\mathrm{C}_{0}$ and $\mathrm{C}_{\mathrm{e}}$ are initial and final concentrations of fluoride in solution in $\mathrm{mg} / \mathrm{L}, \mathrm{V}$ is the volume of solution (L) and $\mathrm{M}$ is the mass of sorbent $(\mathrm{g})$. The effect of $\mathrm{pH}$ was investigated by performing the adsorption experiments at various $\mathrm{pH}$ in the range of 3-11 adjusted by addition of diluted $\mathrm{HCl}$ or $\mathrm{NaOH}$ solution. After adjusting $\mathrm{pH}$ at 3 , affect of contact time (1$30 \mathrm{~min}$ ) in concentrations of 2,5 , and $7.5 \mathrm{mg} / \mathrm{L}$ with $2 \mathrm{~g} / \mathrm{L}$ of sorbent dosage was examined. The effects of competing anions (chloride, nitrate, sulfate, bicarbonate) on fluoride adsorption were investigated by performing fluoride sorption under a fixed fluoride concentration $(2 \mathrm{mg} / \mathrm{L})$ and initial competing anion concentrations of $0.1 \mathrm{M}$ with sorbent dosage of $2 \mathrm{~g} / \mathrm{L}$.

\section{Results and Discussion}

\section{Effect of Solution $\mathrm{pH}$}

$\mathrm{pH}$ of solution is an important factor controlling the surface charge of the adsorbent and the degree of ionization of the materials in the solution. To determine the optimum $\mathrm{pH}$ for the maximum removal of fluoride, the equilibrium sorption of fluoride (with initial fluoride concentration of $2 \mathrm{mg} / \mathrm{L}$ ) was investigated over a $\mathrm{pH}$ range of 3-11. Other maintained conditions were: $20 \mathrm{~min}$ contact time, temperature of $24{ }^{\circ} \mathrm{C}$ and adsorbent concentration of 2 $\mathrm{g} / \mathrm{L}$. It can be seen in Figure 1 as $\mathrm{pH}$ decreases the fluoride removal efficiency decreases. The fluoride sorption also increased due to the fact that for $\mathrm{pH}<\mathrm{pH}_{\mathrm{pzc}}$. Maximum fluoride adsorption was observed at a $\mathrm{pH}=3$. The effect of $\mathrm{pH}$ on fluoride adsorption may be due to chemical and electrostatic interaction between the oxide surface and fluoride ion and also the availability of active sites on the oxide surfaces. Electrostatic interaction between Pumice and fluoride molecules in this $\mathrm{pH}$ range makes the surface of Pumice to become positively charged and therefore attracts the negative fluoride anions. The decrease in removal efficiency at $\mathrm{pH}$ greater than 3 can be attributed to the competition for the active sites by $\mathrm{OH}^{-}$ions and the electrostatic repulsion of anionic fluoride by the negatively charged Pumice surface. Similar observations of formation are presented elsewhere ${ }^{14,30-31}$. 


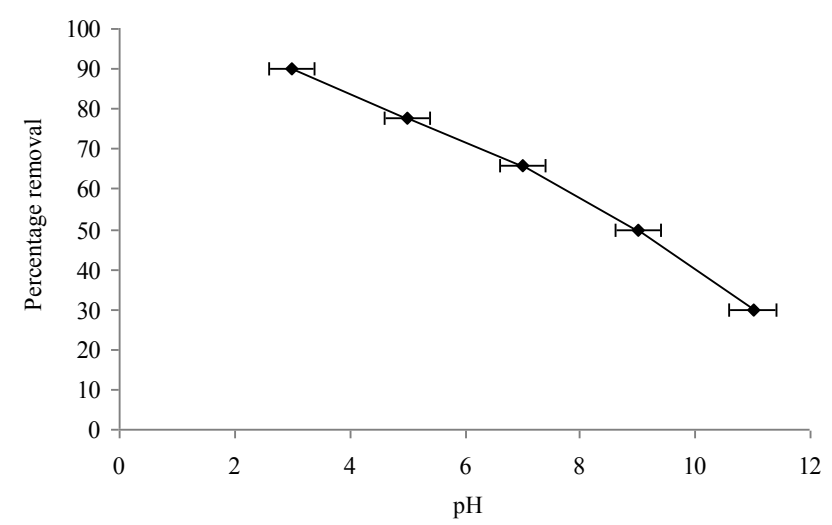

Figure 1. Effect of $\mathrm{pH}$ of solution on $\mathrm{F}$ removal. Conditions: adsorbent dose $2 \mathrm{~g} / \mathrm{L}$, initial fluoride concentration $2 \mathrm{mg} / \mathrm{L}$, temperature $24{ }^{\circ} \mathrm{C}$ and contact time $20 \mathrm{~min}$.

\section{Adsorption Kinetics}

Kinetic models including the pseudo-first-order Eq. (2) and pseudo-second-order Eq. (3) were tested.

\section{Pseudo-First Order Kinetic}

Pseudo-first order kinetic is described by the following equation ${ }^{32}$ :

$$
\frac{d q_{t}}{d t}=K_{1}\left(q_{e}-q_{t}\right),
$$

where $\mathrm{q}_{\mathrm{e}}$ and $\mathrm{q}_{\mathrm{t}}$ are the adsorption capacity of the adsorbate $(\mathrm{mg} / \mathrm{g})$ at equilibrium and at time $\mathrm{t}(\mathrm{min}) ; \mathrm{k}_{1}$ is the pseudo-first-order rate constant. Integration of the Eq. (2) at the boundary of $\mathrm{q}_{\mathrm{t}}=0$ at $\mathrm{t}=0$ and $\mathrm{q}_{\mathrm{t}}=\mathrm{q}_{\mathrm{t}}$ at $\mathrm{t}=\mathrm{t}$, can converted Eq. (2) to the linear form as the following equation:

$$
\log \left(1-\frac{q_{t}}{q_{e}}\right)=-\frac{K_{1}}{2.303} t
$$

\section{Pseudo-Second Order Kinetic}

Pseudo-second order kinetic is expressed as the following equation:

$$
\frac{d q_{t}}{d t}=K_{2}\left(q_{e}-q_{t}\right)^{2}
$$

where $\mathrm{k}_{2}$ is the pseudo-second-order rate constant ( $\left.\mathrm{g} / \mathrm{mg} \mathrm{min}\right)$. Integration of the Eq. (4) at the boundary of $\mathrm{q}_{\mathrm{t}}=0$ at $\mathrm{t}=0$ and $\mathrm{q}_{\mathrm{t}}=\mathrm{q}_{\mathrm{t}}$ at $\mathrm{t}=\mathrm{t}$, can converted Eq. (4) to the linear form as follows:

$$
\frac{t}{q_{t}}=\frac{1}{K_{2} q_{e}^{2}}+\frac{1}{q_{e}} t .
$$

These equations have been used widely for the adsorption of an adsorbate from an aqueous solution. The best fit model was considered based on the regression coefficient $\left(\mathrm{R}^{2}\right)$ 
and the experimental $\mathrm{q}_{\mathrm{e}}$. The rate of adsorption of fluoride was studied at different time intervals of 1-30 min. In kinetic studies, $250 \mathrm{~mL}$ of fluoride solution (5 and $7.5 \mathrm{mgL}^{-1}$ ) with initial $\mathrm{pH}$ solution of 4.1 was agitated with Pumice $(0.3 \mathrm{~g} / 150 \mathrm{cc})$. After a fixed time interval, the adsorbent was separated and the filtrate was analyzed to determine the equilibrium concentration of fluoride. Experiments were repeated for different periods until reaching the adsorption equilibrium. Kinetics of fluoride removal is shown in Figure 2. Parameters of kinetic equations are shown in Table 1. As shown in Table 1 the kinetic of fluoride removal by use of Pumice follows pseudo second order equation $\left(\mathrm{R}^{2}>0.99\right)$.
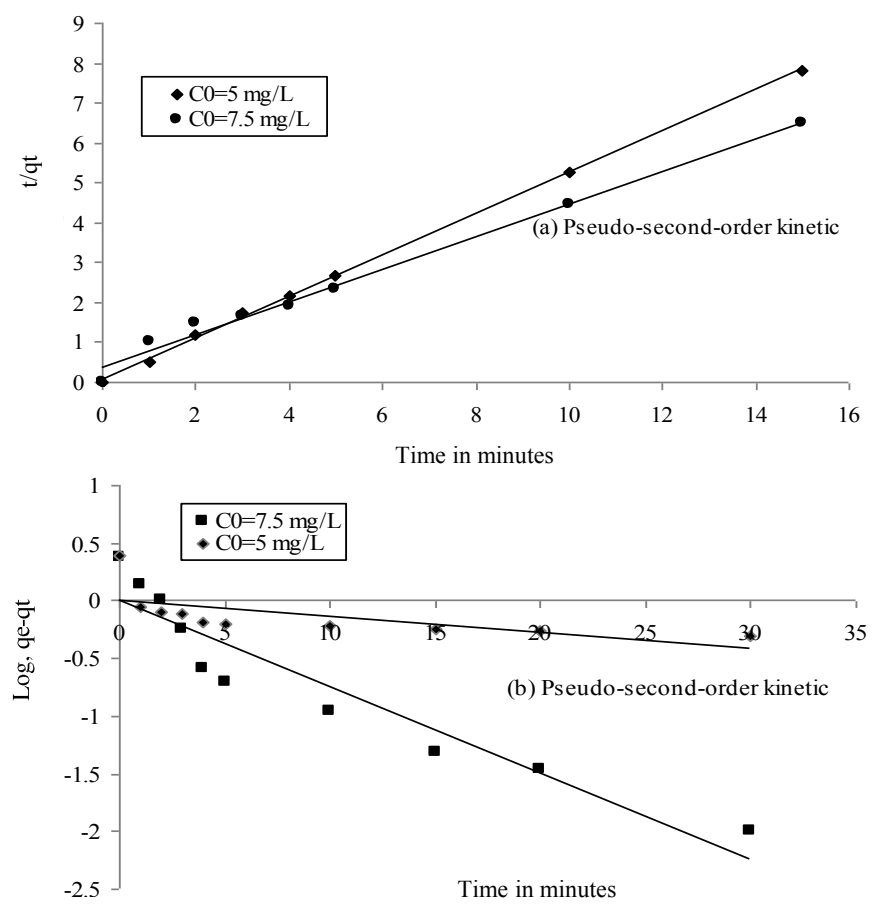

Figure 2. Adsorption kinetics: (a) Pseudo-second-order kinetic and (b) Pseudo-second-order kinetic plots of sorption of fluoride on Pumice.

Table 1. Comparison of pseudo-first-order and pseudo-second-order models parameters, and calculated $q_{\mathrm{e}}(\mathrm{cal})$ and experimental $q_{\mathrm{e}}(a c)$ values for different initial fluoride concentrations.

\begin{tabular}{lccccccc}
\hline \multirow{2}{*}{$\mathrm{C}_{0}, \mathrm{mg} / \mathrm{L}$} & \multicolumn{3}{c}{ Pseudo-first-order model } & \multicolumn{4}{c}{ Pseudo-second-order model } \\
\cline { 2 - 8 } & $\mathrm{q}_{\mathrm{e}}(\mathrm{ac})$ & $\mathrm{q}_{\mathrm{e}}(\mathrm{cal})$ & $\mathrm{k}_{1}$ & $\mathrm{R}^{2}$ & $\mathrm{~K}_{2}$ & $\mathrm{q}_{\mathrm{e}}(\mathrm{cal})$ & $\mathrm{R}^{2}$ \\
\hline 5 & 2 & 2.5 & 0.029 & 0.384 & 0.006 & 2 & 0.999 \\
7.5 & 2.35 & 2.36 & 0.17 & 0.897 & 0.139 & 2.35 & 0.99 \\
\hline
\end{tabular}

\section{Competing Anions Studies}

The adverse effect of various anions like $\mathrm{Cl}^{-}, \mathrm{HCO}_{3}{ }^{-}, \mathrm{SO}_{2}{ }^{-}$, and $\mathrm{PO}_{4}{ }^{3-}$ have been tested on fluoride adsorption rate under a fluoride concentration of $2 \mathrm{mgL}^{-1}$, and initial competing anion concentrations of $0.1 \mathrm{M}$ with sorbent dosage of $2 \mathrm{~g} / \mathrm{L}$. As shown in Figure 3 the removal efficiency was decreased in the presence of anions. The anions reduced the fluoride removal in the order of $\mathrm{PO}_{4}{ }^{3-}>\mathrm{HCO}_{3}>\mathrm{SO}_{4}{ }^{2-}>\mathrm{Cl}^{-}$. This can be explained by considering the stability of different anions associated with adsorbent ${ }^{33}$. This, indicates that $\mathrm{Cl}^{-}$was formed 
in outer-sphere surface complexes, while $\mathrm{SO}_{4}{ }^{2-}$ was formed both in outer and inner-sphere surface complexes ${ }^{34}$. In contrast inner-spherically sorbing anion $\mathrm{PO}_{4}{ }^{3-}$ can significantly be interfered by the sorption of fluoride at elevated concentrations where the sorption competition can be occurred for the limited amount of sorption sites on Pumice ${ }^{35}$. The decrease in fluoride adsorption rate in presence of carbonate was presumably due to the increase in $\mathrm{pH}$ of the solution ${ }^{14}$.

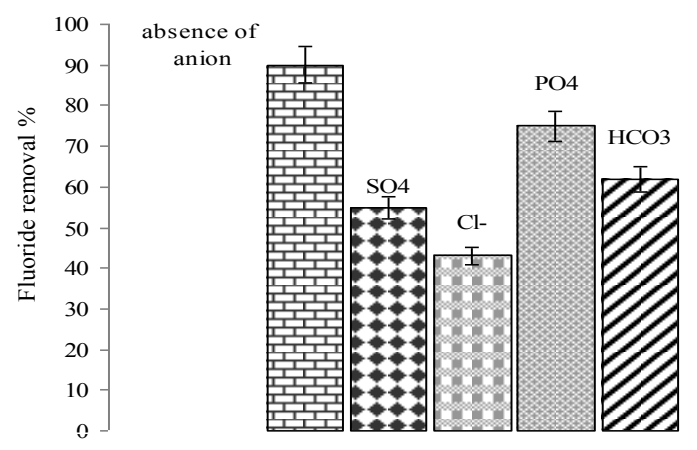

Figure 3. Effect of different ions on fluoride removal by pumice (volume: $150 \mathrm{~mL}$, temperature: $24^{\circ} \mathrm{C}$, adsorbent dose: $2 \mathrm{~g} / \mathrm{L}$, contact time: $20 \mathrm{~min}$, initial $\mathrm{F}$ concentration: $2 \mathrm{mg} / \mathrm{L}$ and concentration of salts: $0.1 \mathrm{M}$ ).

\section{Effect of Contact Time and Initial Nitrate Concentration}

Figure 4 shows the fluoride adsorption kinetic data, plotted as adsorption density (mg F/g pumice) as a function of time, for three different initial fluoride concentrations $(2,5$, and $7.5 \mathrm{mg} / \mathrm{L}$ ) with an initial $\mathrm{pH}=4$. It was noticed that fluoride removal increased with time and then gradually decreased with lapse of time until saturation. The fluoride adsorption was initially speeded up to $20 \mathrm{~min}$, and then it became slow. Therefore, the optimum contact time for adsorption of the fluoride was considered to be $20 \mathrm{~min}$. Fluoride adsorption by Pumice increased when the initial fluoride concentration increased from 2 , to 5 and $7.5 \mathrm{mg} / \mathrm{L}$ (Figure 4). This can be related to the increase in the driving force of the concentration gradient, as an increase in the initial fluoride concentration ${ }^{35}$.

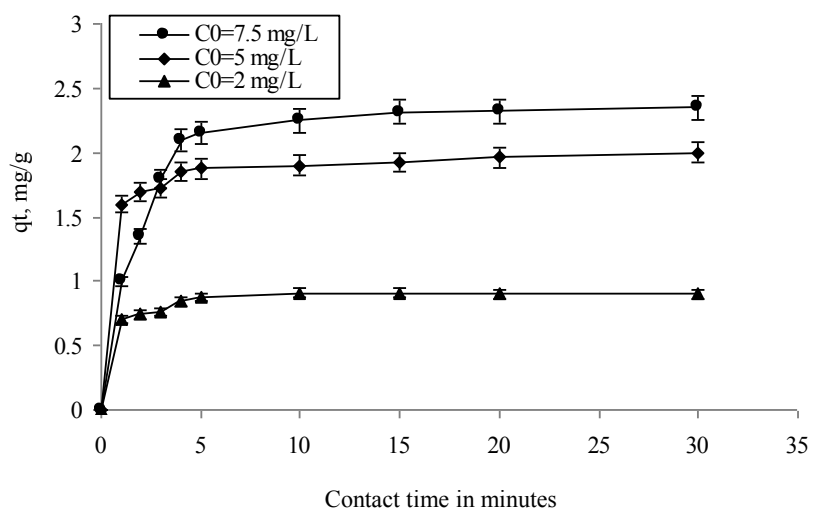

Figure 4. Effect of contact time and initial fluoride concentration on sorption of fluoride on Pumice (temperature $=24^{\circ} \mathrm{C}$, sorbent dose $=2 \mathrm{gL}^{-1}$, equilibrium $\mathrm{pH}=\sim 4.1$ ). 


\section{Characterization of Pumice}

A physicochemical characteristic of the Pumice sample by XRF (X-ray fluorescence) is shown in Table 2. The $\mathrm{SiO}_{2}$ contents of Pumice are 74\%. It appears that there may be a correlation between silica content and internal porosity in pumices. The detailed physicochemical characteristics of Pumice fractions are presented elsewhere ${ }^{28,36}$. The SEM images of Pumice are shown in Figure 5. As shown in Figure 5 the naked Pumice particles had a mean diameter of $126 \mathrm{~nm}$. As seen from Figure 5 the sorbent does not possess any well defined porous structure (only few pores on the surface). EDX analyses were performed to determine the elemental constituents of Pumice (Figure 6). It shows that the presence of $\mathrm{Si}$ in large content appears in the spectrum other than the principal metal oxides elements. The weight percent of $\mathrm{Si}, \mathrm{Al}, \mathrm{Fe}$ and $\mathrm{K}$ were found to be 71.84, 15.43, 7.12 and 5.61 , respectively.

The X-ray diffraction pattern of Pumice is shown in Figure 7. The x-ray spectrum of Pumice shows more amorphous nature, which allows a better accessibility to fluoride and thus a better activity.

Table 2. Percentages of the main constituents of Pumice found by XRF.

\begin{tabular}{lccccccccc}
\hline Oxide & $\mathrm{SiO}_{2}$ & $\mathrm{Al}_{2} \mathrm{O}_{3}$ & $\mathrm{~K}_{2} \mathrm{O}$ & $\mathrm{Na}_{2} \mathrm{O}$ & $\mathrm{Fe}_{2} \mathrm{O}_{3}$ & $\mathrm{CaO}$ & $\mathrm{MgO}$ & Others & Total \\
\hline Pumice (wt \%) & 74 & 13.72 & 4.66 & 3.65 & 1.98 & 1.16 & 0.32 & 1.05 & 100 \\
\hline
\end{tabular}

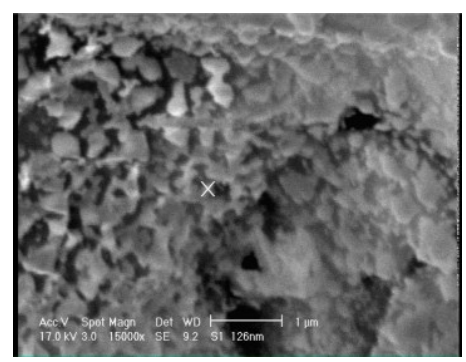

Figure 5. SEM image of Pumice.

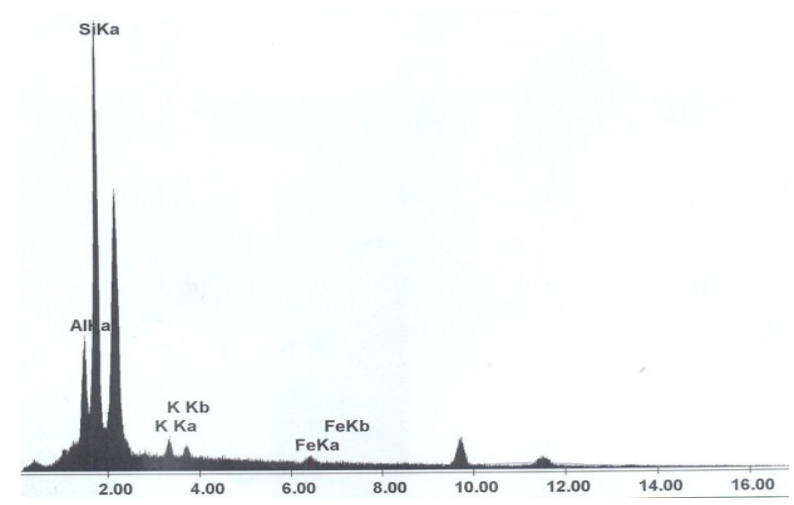

Figure 6. EDX results of the Pumice. 


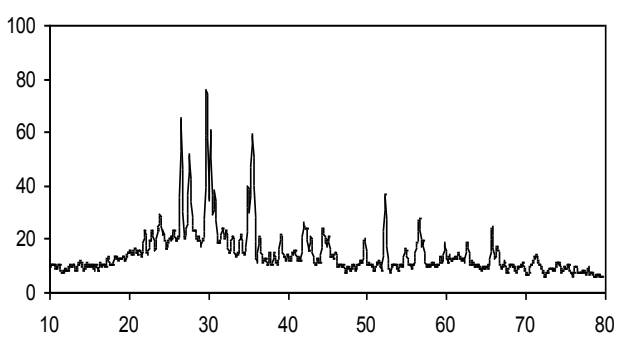

Figure 7. XRD pattern of Pumice.

\section{Isothermal Studies}

Adsorption isotherms are equations for description of equilibrium phase between sorbent and an aqueous solution. Freundlich models are empirical models for rough sorbents which are applicable for systems with a single dissolved material. Longmuir isotherm can be used for physical sorption in a single layer ${ }^{37}$. In the present study experimental data of adsorption equilibrium was described by use of Longmuir and Freundlich isotherms and could be shown as following:

Equation of Longmuir isotherm can be expressed as:

$$
q_{e}=\frac{q_{m} b C_{e}}{1+b C_{e}}
$$

By taking the Longmuir of above equation, linear Longmuir equation becomes:

$$
\frac{c_{e}}{q_{e}}=\frac{1}{q_{m} b}+\frac{1}{q_{m}} c_{e,}
$$

where $\mathrm{q}_{\mathrm{e}}$ is the amount of sorbed fraction in mass unit of sorbent $(\mathrm{mg} / \mathrm{gr}), \mathrm{C}_{e}$ is equilibrium sorbate concentration after adsorption $(\mathrm{mg} / \mathrm{L}), \mathrm{q}_{\mathrm{m}}$ is adsorption capacity and $\mathrm{b}$ is the Langmuir constant related to energy of sorption ${ }^{35}$ and can be commuted by plotting $\mathrm{C}_{\mathrm{e}} / \mathrm{q}_{\mathrm{e}} v s . \mathrm{C}_{\mathrm{e}}$. The influence of adsorption isotherm shape has been discussed to examine whether adsorption is favorable in terms of $\mathrm{R}_{\mathrm{L}}$, a dimensionless constant referred to as separation factor or equilibrium parameter. $\mathrm{R}_{\mathrm{L}}$ is defined by the following relationship:

$$
R_{L}=\frac{1}{\left(1+b C_{0}\right)}
$$

$\mathrm{C}_{0}$ is the initial concentration. From the above factor, type of sorption can be indicated. The $R_{L}$ value indicates the shape of isotherm. $R_{L}$ values between 0 and 1 indicate favorable adsorption, while $\mathrm{R}_{\mathrm{L}}>1, \mathrm{R}_{\mathrm{L}}=1$, and $\mathrm{R}_{\mathrm{L}}=0$ indicate unfavorable, linear, and irreversible adsorption isotherms, respectively ${ }^{38}$. Equation of Freundlich isotherm can be expressed as:

$$
q_{e}=K_{f} C_{e}^{1 / n}
$$

The equation is conveniently used in the linear form by taking the logarithm of both sides as:

$$
\log q_{e}=\log k_{F}+\frac{1}{n} \log c_{e}
$$

$\mathrm{C}_{\mathrm{e}}(\mathrm{mg} / \mathrm{g})$ is equilibrium concentration; $\mathrm{q}_{\mathrm{e}}(\mathrm{mg} / \mathrm{g})$ is capacity of sorption in moment of equilibrium and $\mathrm{K}_{\mathrm{f}}$ and $\mathrm{n}$ are Freundlich's constants ${ }^{39}$. $\mathrm{K}_{\mathrm{f}}$ represents amount of sorption 
tendency to the surface of sorbent. The higher values of $\mathrm{K}_{\mathrm{f}}$ represent the more tendency of sorption by sorbent ${ }^{37}$. The $\mathrm{n}$ value in the range of $2-10$ indicates a favorable adsorption process $^{32}$. Isothermal studies of fluoride removal are shown in Figure 8.

Table 3 presents the parameters of the Langmuir and Freudlich isotherms. It shows that the isotherm data has been fitted to the Freudlich model, which provides the best results for these sorts of curves based on the correlation coefficients $(>0.995)$. The value of $1 / \mathrm{n}(0.34)$ lying between 0.1 and 1.0 and that of $n$ (2.95) lying in the range 1-10 both confirmed the favorable conditions of sorption ${ }^{40}$. Also it is shown in Table 3 that the magnitude of the Langmuir constant ' $b$ ' has small values $\left(0.07 \mathrm{~L} \mathrm{mg}^{-1}\right)$, which indicates a low heat of adsorption ${ }^{29}$. The values of $R_{L}$ calculated according to Eq. (7) to be 0.65 . These $R_{L}$ values lying between 0 and 1 indicated favorable conditions for sorption. The values of $q_{m}$ obtained from Langmuir model is $13.51 \mathrm{mg} / \mathrm{g}$. Satisfactory fitting of the Freundlich model to the adsorption isotherm suggests that the adsorption of fluoride involves the multilayer coverage on the surface of the Pumice and assumes an infinite supply of untouched adsorbent sites and tends to represent heterogeneous materials better than other models ${ }^{41}$.

Table 3. Langmuir and Freundlich constants for the adsorption of fluoride on Pumice.

\begin{tabular}{cccccrr}
\hline \multicolumn{3}{c}{ Freudlich isotherm } & \multicolumn{5}{c}{ Langmuir isotherm } \\
\hline $\mathrm{k}_{\mathrm{f}}$ & $\mathrm{n}$ & $\mathrm{R}^{2}$ & $\mathrm{q}_{\mathrm{m}}, \mathrm{mg} / \mathrm{g}$ & $\mathrm{b}, \mathrm{L} / \mathrm{mg}$ & $\mathrm{R}_{\mathrm{L}}$ & $\mathrm{R}^{2}$ \\
\hline 2.15 & 2.95 & 0.995 & 13.51 & 0.07 & 0.65 & 0.978 \\
\hline
\end{tabular}
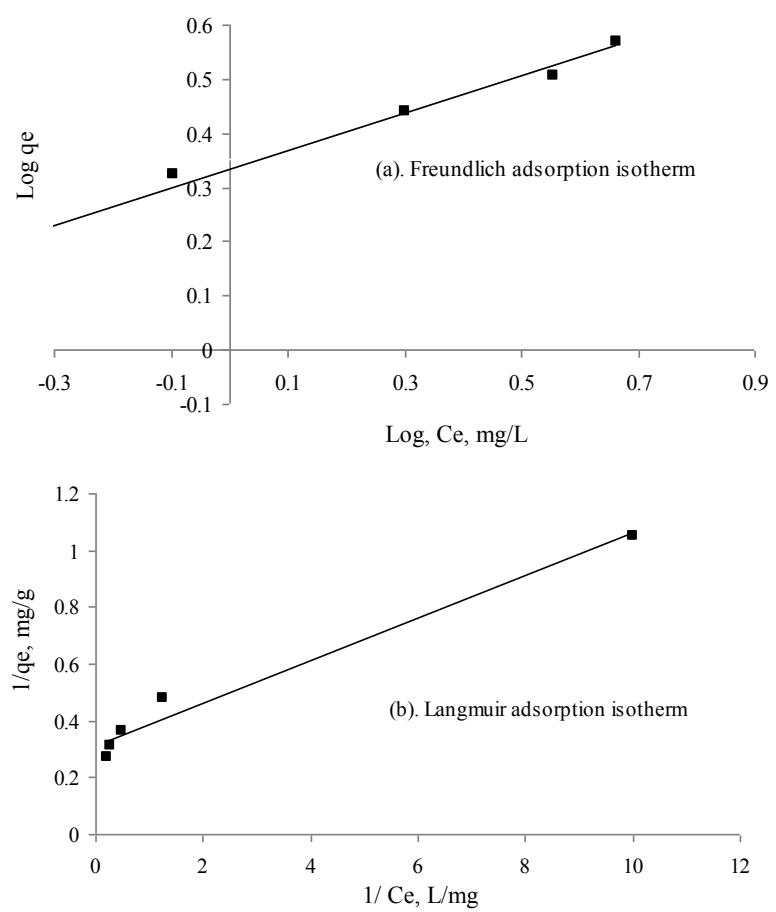

Figure 8. Isothermal studies: (a) Freundlich adsorption isotherm and (b) Langmuir adsorption isotherm. 


\section{Conclusion}

This study has demonstrated that Pumice can be used as effective adsorbents for fluoride removal from aqueous solutions. The adsorbent prepared in this study was cheap and effeceient in removal of fluoride than other adsorbents. Results also indicate that the fluoride adsorption reaches maximum in $\mathrm{pH}=3$, then decreases with further increase in $\mathrm{pH}$.The addition of onions had a negative effect on the removal effeciency of the Pumice. The results of these isothermal studies showed that fluoride removal follow of Freundlich isotherm model $\left(\mathrm{R}^{2}>0.995\right)$. This fact indicated that the sorbent is heterogeneous and that the sorption reaction followed the pseudo-second order kinetics. Fluoride removal according to their affinity on the Pumice surface in the following order: $\mathrm{PO}_{4}{ }^{3-}>\mathrm{HCO}_{3}>\mathrm{SO}_{4}{ }^{2-}>\mathrm{Cl}^{-}$. The uptake is $13.51 \mathrm{mg} / \mathrm{g}$ and it is depended on the fluoride initial concentration and the $\mathrm{pH}$. The results obtained from the present study demonstrated that the Pumice can be used as a no cost, highly effective and easy available adsorbent for removal of fluoride from aqueous solutions.

\section{References}

1. Huang H, Schwab K and Jacangelo J G, Environ Sci Technol., 2009, 43, 3011-3019.

2. Rahmani A, Rahmani K, Mahvi A H and Usefie M, Fluoride, 2010, 43, 187-193.

3. Driscoll W, Horowitz H, Meyers R, Heifetz S, Kingman A, and Zimmerman E, The Journal of the American Dental Association., 1983, 107, 42.

4. Montomery J, JOHN WILEY AND SONS, NEW YORK, NY(USA), 1985, 1985.

5. Mahvi A, Zazoli M, Younecian M, Nicpour B, and Babapour A, J Med Sci., 2006, 6, 658661.

6. Guidelines for drinking-water quality [electronic resource]: incorporating 1st and 2nd addenda, Vol.1, Recommendations. - 3rd ed.

7. Ayoob S and Gupta A, Critical Rev Environ Sci Technol., 2006, 36, 433- 487.

8. Hussain J, Hussain I and Sharma K, Environ Monit Assess., 2010, 162, 1-14.

9. Dobaradaran S, Mahvi A H and Dehdashti S, Fluoride 2008, 41, 93-94.

10. Doull J, Boekelheide K, Farishian B, Isaacson R, Klotz J, Kumar J, Limeback H, Poole C, Puzas J and Reed N, National Academies Washington., 2006, 205-223.

11. Mahvi A H, Zazoli M A, Younecian M and Esfandiari Y, Fluoride., 2006, 39, 266-268.

12. Dobaradaran S, Mahvi A H, Dehdashti S, Abadi D R V, and Tehran I, Fluoride., 2008, 41, 220-226.

13. Dobaradaran S, Mahvi A H, Dehdashti S, and Shoara R, Fluoride., 2009, 42, 50-53.

14. Kumar E, Bhatnagar A, Kumar U and Sillanpaa M, J Hazard Mater., 2010.

15. Mahramanlioglu M, Kizilcikli I and Bicer I, J Fluorine Chem., 2002, 115, 41-47.

16. Saha S, Water Res., 1993, 27, 1347-1350.

17. Ruixia L, Jinlong G, and Hongxiao T, J Colloid Interface Sci., 2002, 248, 268-274.

18. Kabay N, Arar O, Samatya S, Yüksel U and Yüksel M, J Hazard Mater., 2008, 153, 107-113.

19. Sehn P, Desalination., 2008, 223, 73-84.

20. Ghorai S and Pant K, Sep Purif Technol., 2005, 42, 265-271.

21. Daifullah A, Yakout S, and Elreefy S, J Hazard Mater., 2007, 147, 633-643.

22. Wang S and Wu H, J Hazard Mater., 2006, 136, 482-501.

23. Kawasaki N, Ogata F, Tominaga H and Yamaguchi I, J Oleo Sci., 2009, 58, 529-535.

24. Dey S, Goswami S and Ghosh U C, Water, Air Soil Pollut., 2004, 158, 311-323.

25. Das N, Pattanaik P and Das R, J Colloid Interface Sci., 2005, 292, 1-10.

26. Yamashita H, Kawasaki S, Yuan S, Maekawa K, Anpo M and Matsumura M, Catal Today, 2007, 126, 375-381.

27. Boldaji M R, Mahvi A H, Dobaradaran S and Hosseini S S, Inter J Environ Sci Technol., 2009, 6, 629-632.

28. Kitis M and Kaplan S, Chemosphere, 2007, 68, 1846-1853.

29. Sujana M, Pradhan H, and Anand S, J Hazard Mater., 2009, 161, 120-125. 
30. Kumar E, Bhatnagar A, Ji M, Jung W, Lee S H, Kim S J, Lee G, Song H, Choi J Y and Yang J S, Water Res., 2009, 43, 490-498.

31. Mohapatra M, Rout K, Singh P, Anand S, Layek S, Verma H, and Mishra B, $J$ Hazard Mater., 2010.

32. Li Y, Gao B, Wu T, Sun D, Li X, Wang B, and Lu F, Water Res., 2009, 43, 3067-3075.

33. Islam M, Mishra P C, and Patel R, Chem Eng J., 2010.

34. Tang Y, Guan X, Wang J, Gao N, McPhail M R, and Chusuei C C, J Hazard Mater., 2009, 171, 774-779.

35. Bhatnagar A, Kumar E, and Sillanpää M, Chem Eng J., 2010.

36. Catalfamo P, Arrigo I, Primerano P, and Corigliano F, J Hazardous Mater., 2006, 134, 140-143.

37. Dogan M, Alkan M, Demirbas O, Ozdemir Y, and Ozmetin C, Chem Eng J., 2006, 124, 89-101.

38. Afkhami A, Saber-Tehrani M, and Bagheri H, J Hazard Mater., 2010, 181, 836- 844.

39. Janos P, Buchtova H and Ryznarova M, Water Res., 2003, 37, 4938-4944.

40. Jiménez-Reyes M and Solache-Ríos M, J Hazard Mater., 2010, 180, 297-302.

41. Bansiwal A, Thakre D, Labhshetwar N, Meshram S and Rayalu S, Colloids Surfaces B: Biointerfaces., 2009, 74, $216-224$. 


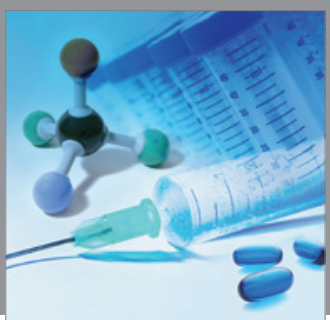

International Journal of

Medicinal Chemistry

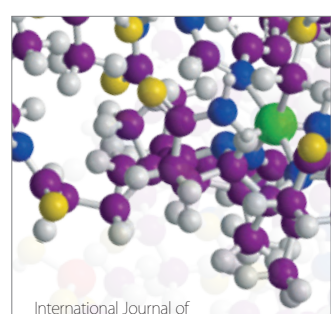

Carbohydrate Chemistry

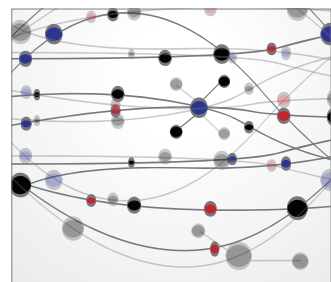

The Scientific World Journal
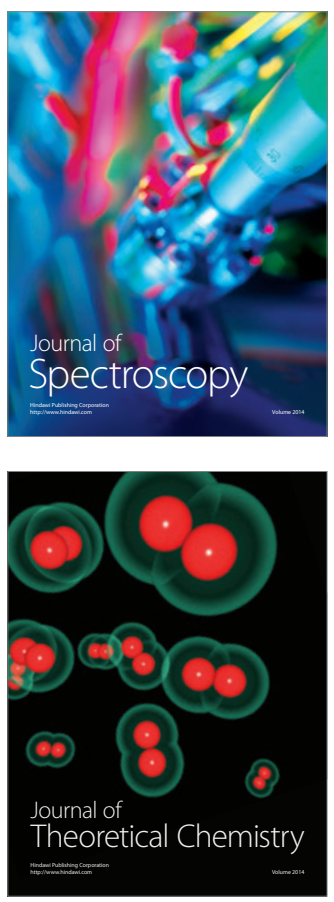
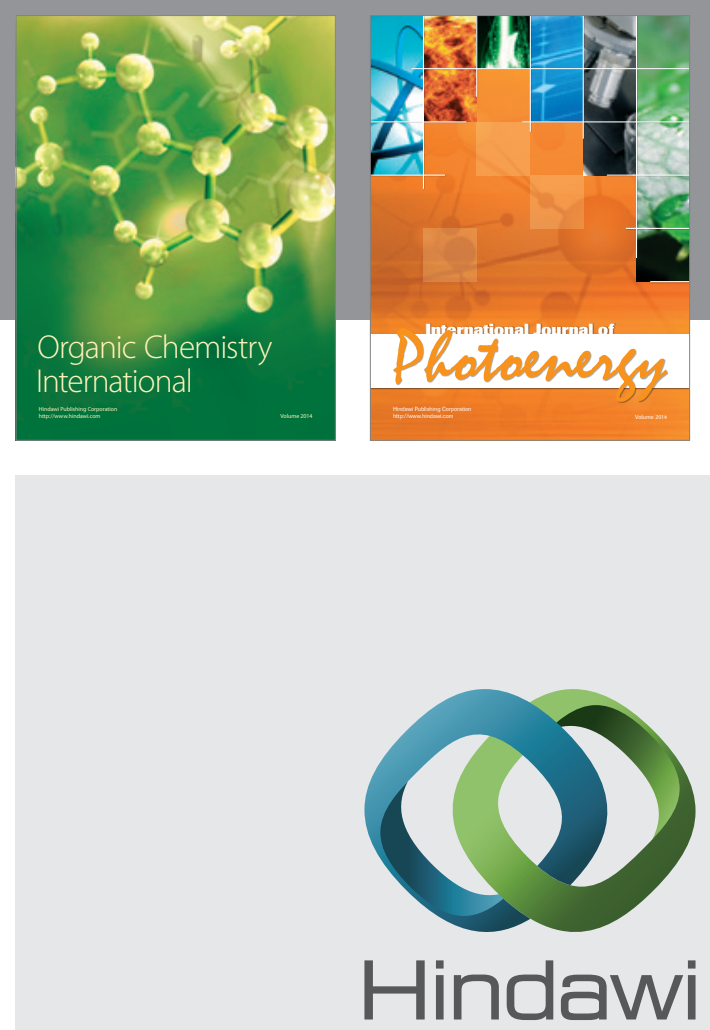

Submit your manuscripts at

http://www.hindawi.com
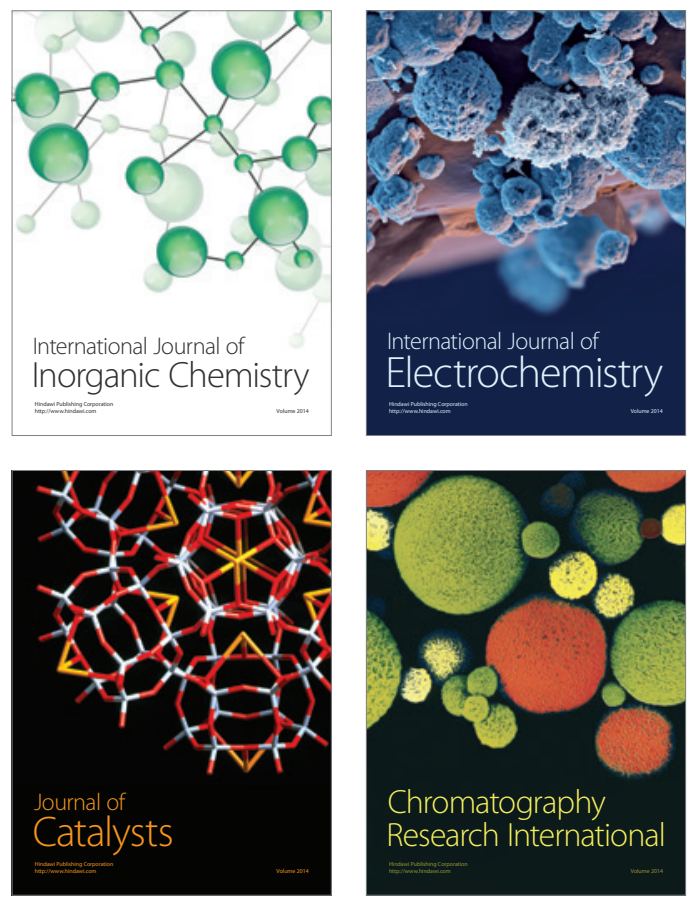
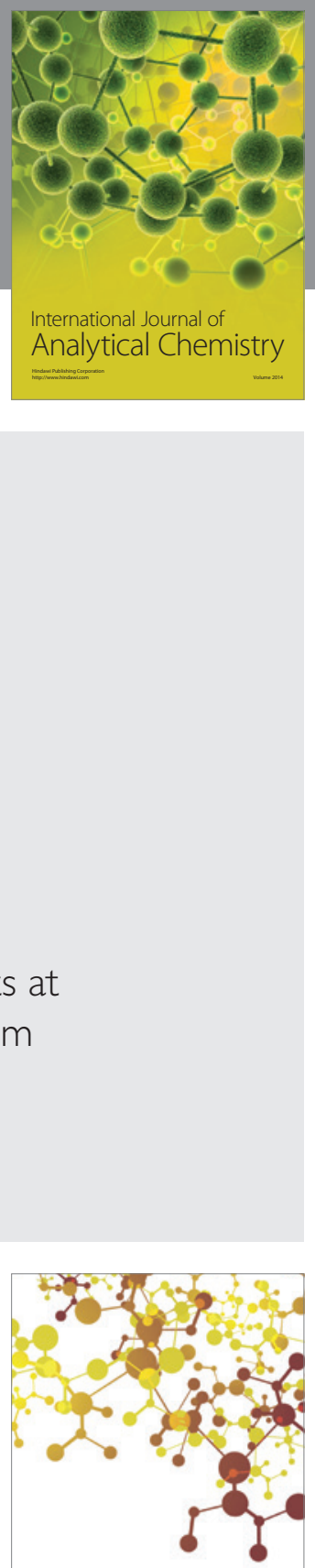

Journal of

Applied Chemistry
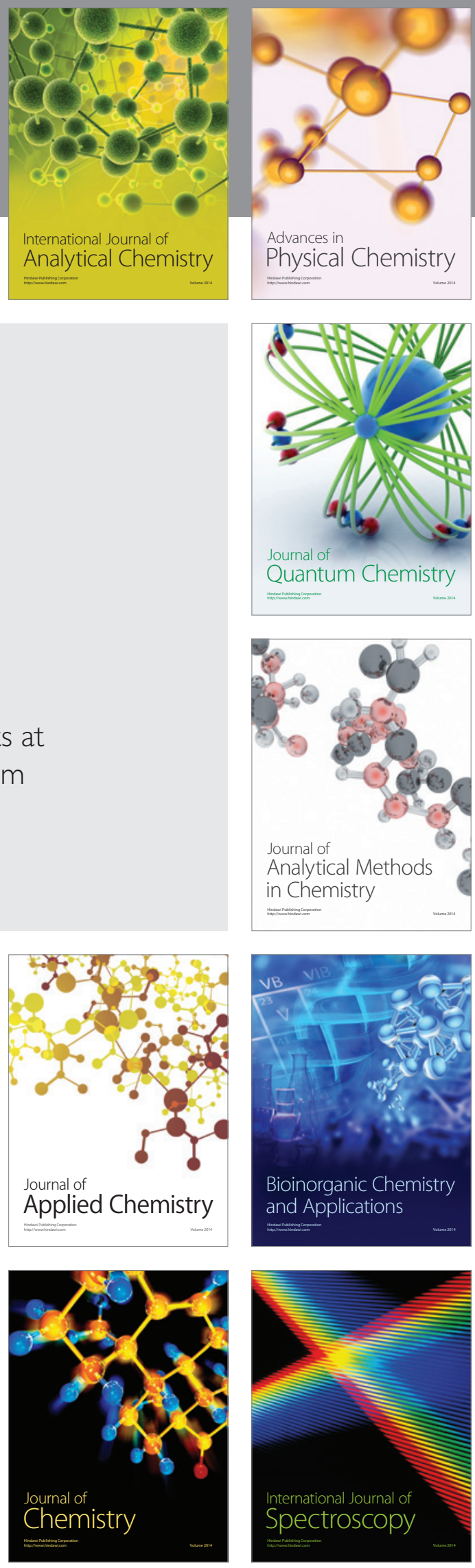